\title{
Kara-Kalpak Language
}

National Cancer Institute

\section{Source}

National Cancer Institute. Kara-Kalpak Language. NCI Thesaurus. Code C153965.

A T urkic language spoken by the Karakalpak people in the Karakalpakstan republic of Uzbekistan. 